\title{
Student Leadership through the Lens of Lebanese Public School Students
}

\author{
Najah A. R. Ghamrawi ${ }^{*}$, Norma Ghamrawi², Tarek Shal ${ }^{3}$ \\ ${ }^{1}$ Educational Psychology, Faculty of Education, Lebanese University, Beirut, Lebanon \\ ${ }^{2}$ Educational Leadership and Management, Faculty of Education, Lebanese University, Beirut, Lebanon \\ ${ }^{3}$ Educational Technology, Lebanese University, Beirut, Lebanon \\ Email: ^najahghamrawi@hotmail.com,dr.norma_ghamrawi@hotmail.com, tarek_shal@hotmail.com
}

How to cite this paper: Ghamrawi, N. A. R., Ghamrawi, N., \& Shal, T. (2018). Student Leadership through the Lens of Lebanese Public School Students. Open Journal of Leadership, 7, 33-48. https://doi.org/10.4236/ojl.2018.71003

Received: January 30, 2018

Accepted: March 11, 2018

Published: March 14, 2018

Copyright (C) 2018 by authors and Scientific Research Publishing Inc. This work is licensed under the Creative Commons Attribution International License (CC BY 4.0).

http://creativecommons.org/licenses/by/4.0/

\section{(c) (i) Open Access}

\begin{abstract}
This study investigated the perceptions of students regarding the concept of student leadership within the Lebanese school context. The study surveyed 410 high school students from 4 public schools in Beirut, Lebanon. Data was collected via a survey consisting of 20 items developed and adapted from the LPI survey of Kouzes \& Posner (2014). It addresses students' perception of leadership around 5 areas: 1 ) modeling the way; 2 ) inspiring a shared vision; 3) challenging the process; 4) enabling others to act; and 5) encouraging the heart. In addition, a focus group interview was conducted with 8 students, two from each surveyed school. The interview focused on collecting deep empathetic qualitative data about how the realization of student leadership in their schools would impact on them. Quantitative data was analyzed using SPSS 21.0 for windows, while qualitative data was analyzed thematically. Results indicated that students recognized strengths and weaknesses of student leadership and that if well established, students would be more inclined to learn in their schools.
\end{abstract}

\section{Keywords}

Educational Leadership, Student Leadership, School Leadership, Educational Psychology

\section{Introduction}

A growing body of research is affirming the shortage of leadership roles among adult lives (Dempster, 2006) and careers (Kouzes \& Posner, 2014). This era also marks a decline in potential education leaders (Grogan \& Shakeshaft, 2010) and community leadership (Gannon, 2001). The perceived shortage of leadership has renewed the interest in student leadership development (Hirsch Jr., 2010) as it 
empowers students to impact their own learning and their school environment, and to be well prepared for meaningful roles in the wider community (Black \& Walsh, 2009).

A recent publication conducted by Ghamrawi (2016) that was commissioned by UNESCO Paris, provided a gloomy image of school leadership in the Arab region. The report concludes that the hierarchical bureaucratic and authoritarian styles of leadership are dominant and often impact on school leadership styles endorsed by school leaders (Ghamrawi, 2016). Ghamrawi (2016) argued that distributed leadership was not evident in any of the 22 Arab states, including Lebanon. This entails that forms of leadership that usually prevail when leadership is distributed are missing, including teacher leadership \& student leadership. Likewise, the status of school leadership has been raised as a global concern in the education for all global monitoring report (EFA, 2012).

Knowing that the expenditure on education in the region is notably variable, Lebanon spends the lowest of its overall budget on education (UNDP, 2013). Surprisingly, the Lebanese Ministry of Education and Higher Education (MEHE) has addressed the importance of school leadership development through specialized leadership training for school principals (Ghamrawi, 2016). While the program has been developed and delivered at international standards, school leaders were not able to walk its talk in practice due to MEHE decrees and laws which remained static and did not evolve with the evolution of school leaders' knowledge and skills (Ghamrawi, 2016).

The growing awareness of the importance of school leadership within the Lebanese educational system has reached its zenith with the publication of the Effective School Standards (EFA, 2012) which puts distributed leadership at the heart of the profile of effective schools. This acknowledgement of the importance of distributed leadership entails an implicit acceptance of the prevailance of other forms of leadership in public schools including: subject leadership, teacher leadership and student leadership (Ghamrawi, 2011).

While all forms of leadership that surface in schools when distributed leadership is endorsed are equally important, this study focused on student leadership. This decision has been made on the basis of the importance of student leadership in terms of impacting positively on student learning (Al-Jammal \& Ghamrawi, 2013).

\subsection{Purpose of the Study}

This study aimed at investigating the perception of students pertaining to student leadership within the Lebanese school context. The investigation targeted the principles and values that underpin the concept of student leadership in a selection of Lebanese public schools and aimed at finding out how students perceive those principles and values, and their perceptions of the operational practices of the concept within their school. Besides, it aimed at investigating students views about the impact of student leadership on them should it get realized in their schools. Particularly, this study was guided by the following re- 
search questions:

What are the student leadership skills that mostly prevail within Lebanese schools?

What are students' perceptions as to how student leadership may be enhanced in their schools?

How would the realization of student leadership impact on students in their schools?

\subsection{Importance of the Study}

Student leadership is of importance to student development, school culture, and the wider community (Chapman \& Aspin, 2001). Lavery (2006: p. 3) pointed that "developing and affirming the intrinsic leadership potential of all Year 12 students is a fundamental means by which schools can prepare senior students for the challenges of the future".

More importantly, student leadership is integral for the realization for $21^{\text {st }}$ century skills which are considered essential for student learning in this era P21 (Partnership for 21st Century Skills, 2011). In fact, $21^{\text {st }}$ century skills mainly: communication, collaboration, critical thinking a kills and creativity; are basically among the bold schools endorsed by student leaders (Ghamrawi, Ghamrawi, \& Shal, 2017).

This study tracked the leadership experiences, attitudes and perceptions of students and investigated the ways in which the Lebanese public schools approach the development of their young pupils as leaders for the future.

With the limitation of the published literature about school leadership in Lebanon in general, and particulary about student leadership; this study constitutes a worth resource to expand the knowledge of the topic. While it is expected that the study will be of value within the Lebanese context, it is also possible that its findings provide an incentive for replication elsewhere using its research methodology.

\section{Review of Related Literature}

\subsection{Leadership}

"Leadership is one of the most observed and least understood phenomena on earth" (cited in Adams \& Keim, 2000: p. 259). According to the Social Change Model, leadership is "a purposeful, collaborative, values-based process that results in positive social change" (Komives, 2011). It was considered by the Ofsted of the UK as the corner stone for any development or reform (cited in Ghamrawi, 2011).

Scholars have realized major changes between the leadership of the 19th and 20th century (Rost, 1993). Through the late 19th century, few individuals had the excellence of being leaders and thus the leadership development was based on the individual. This "leader-centric" approach resulted in two groups, leaders and followers, and influenced the leadership perspectives until the mid-20th 
century. However, Rost (1993) noted that leadership approach during the post-industrial era changed into a relational process between both leaders and followers where leaders would empower their followers to become leaders themselves. Then in an approach that combines both the leader/follower relationship and the postindustrial leadership paradigm. Day (2013) noted the reciprocal leadership which emphasizes that leaders and followers should interact in a mutually beneficial relationship.

There are mainly five models of leadership within this literature review, namely: transactional, transformational, charismatic, servant, and distributed leadership. Transactional leadership is task and relationship oriented (Tuohy, 1999), and "involves an exchange process between leaders and followers, whereby followers get immediate, tangible rewards for carrying out the leader's orders" (Locke, 1999: p. 5). By contrast, transformational leadership involves leaders motivating followers to improve present attitudes and assumptions (Friedman, 2004).

Charismatic leadership is based on the admiration and respect shown to a leader by subordinate co-workers, and is grounded in trust, honesty and credibility (Friedman, 2004). Servant leadership focuses chiefly on the concept of service, and emerges from a natural desire for leaders to serve first before leading (Ghamrawi \& Al-Jammal, 2013). Distributed leadership is defined by the interactions between people and their situation (Spillane, 2005); and it acknowledges that there are multiple leaders in an organisation (Ghamrawi, 2011), and that leadership capability and capacity is not fixed, but can be developed and extended (Ghamrawi, 2011).

Leadership is necessary in everyone's life regardless of the field (Ghamrawi \& Al-Jammal, 2013), there is no surprise that the contemporary education place high value on developing leadership skills among the youth (Dial, 2006). One of the complex issues, when it comes to leadership development, is the responsibility of educating the nations' future leaders. The various social institutions and community groups, may help in the development of young leaders, however, these institutions are unable to develop leadership on a national scale due to limited resources (Black \& Walsh, 2009). According to Dewey (1916/2012), schools and colleges play the role of vehicles for that kind of education that society could not otherwise provide. The bottom line is that the duty of educating future leaders often falls on the shoulders of schools, colleges and universities (Eich, 2008).

\subsection{Student Leadership}

Leadership education is a crucial component of student development (Ghamrawi, Ghamrawi, \& Shal, 2017). There are many skills and competencies that need to be targeted through leadership development programs. Student leadership development and education programs provide students with opportunities to demonstrate and develop their leadership skills at a young age (Leithwood et al., 2004). It is not just about teaching a student how to be the captain or a student 
government official, out in front leading a team or small group. Leadership is about much more. It is about understanding systems, people, and knowing right from wrong and doing the right thing (Komives, Dugan \& Owen, 2011).

Student leadership incorporates the purposes that are often described as student participation, student agency or student voice (Leithwood et al., 2004). Student leadership targets the principles of education and its practices that grant the necessary opportunities for the youth to support their voices, to share in decision-making, and to comprehend their rights and responsibilities as effective citizens (Black \& Walsh, 2009). Schools of the twenty first century are institutions devoted to qualify the students with the skills to lead within their schools, to impact on their learning and school environment, and to be prepared to participate effectively in their community (Ghamrawi, Ghamrawi, \& Shal, 2017).

Effective student leadership respects the perspectives of students and their opinions towards issues that matter in the classroom, the school, and the community (Komives, Dugan, \& Owen, 2011). Students are trained to be effective leaders when they are active in decision making and in participating active citizenship (Black \& Walsh, 2009). Schools enable students' leadership through various aspects such as: valuing student voice, modifying school leadership structures to promote student participation, encouraging leadership skills in the classroom, implementing pedagogy that enhances active citizenship, and forming partnerships with the community (Walsh \& Black, 2011).

\subsection{Impact of Student Leadership}

Student leadership is important to student development, school culture, and the wider community (Ghamrawi \& Al-Jammal, 2013). Developing student leadership through specific programs is crucial to promoting social responsibility, community leadership, active citizenship and service leadership (Chapman \& Aspin, 2001).

Pedersen, Yager \& Yager (2012) proposed that student leadership builds a positive school environment, instills positive emotional growth in student leaders, and constitutes a positive model that influences other students. Studies suggest that students who are involved in leadership activities are "more likely to report growth in their commitment to civic responsibility, conflict resolution skills, ability to plan and implement programs and activities, and willingness to take risks" (Cress, Astin, Zimmerman-Oster, \& Burkhardt, 2001: p. 18).

The practices of student leadership are among youths' rights, as they allow students to become active participants in their schools and communities, and should be reinforced by teachers and principals (McInerney, 2009). The benefits of effective student leadership are more than the high school graduation rates, as it has the potential of developing critical student competencies and constructing a positive school climate (Steinberg \& Li, 2014).

Student leadership is not only valuable for the improvement of schooling but also for the advancement of the society (DEECD, 2009). When students participate in the school's life and community life, the development of their skills is 
fostered and leading to active citizenship (Ghamrawi \& Al-Jammal, 2013).

Students in our education system and later on in their lives have to deal with complex problems and they will need advanced and complex competencies and skills to do so (Bowman, 2014). For this purpose van Velsor \& Wright, (2012) identified essential competencies conducive for that: adaptability, effective communication, learning ability, and multicultural awareness. Likewise, Kouzes \& Posner (2014) suggest five essential skills to become a student leader capable of confronting challenges of this era. These are presented in Figure 1.

Figure 1 presents the outcome of 30 years experience for Kouzes \& Posner dealing with student leadership. They propose five practices commonly endorsed by students who practice leadership, including: 1) Modelling the Way; 2) Inspiring a Shared Vision; 3) Challenging the Process; 4) Enabling others to Act; and 5) Encouraging the Heart.

So according to Kouzes \& Posner (2014) students need a role model for them to develop leadership skills, share a common vision with colleagues and the community member; get challenged beyond their comfort zones; and empowering others. Yet these all may not fruit unless the hearts and not only the brains of students are motivated and encouraged to take on leadership roles.

\subsection{Student Leadership in Lebanon}

Bowman (2014: p. 59) states that leadership is a huge responsibility for our education system faced with global challenges such as "self-interest, incivility, greed, coercive power, zealotry, and violent extremism" and he sees leadership as a way to help students make a difference in this world. "Leadership development does not happen in a vacuum," and efforts are needed to consider into account the gender and background differences (Ruderman, 2004: p. 274).

A study conducted by Ghamrawi \& Al-Jammal (2013) addressed the provision of student leadership in private school settings in Lebanon. A survey involving

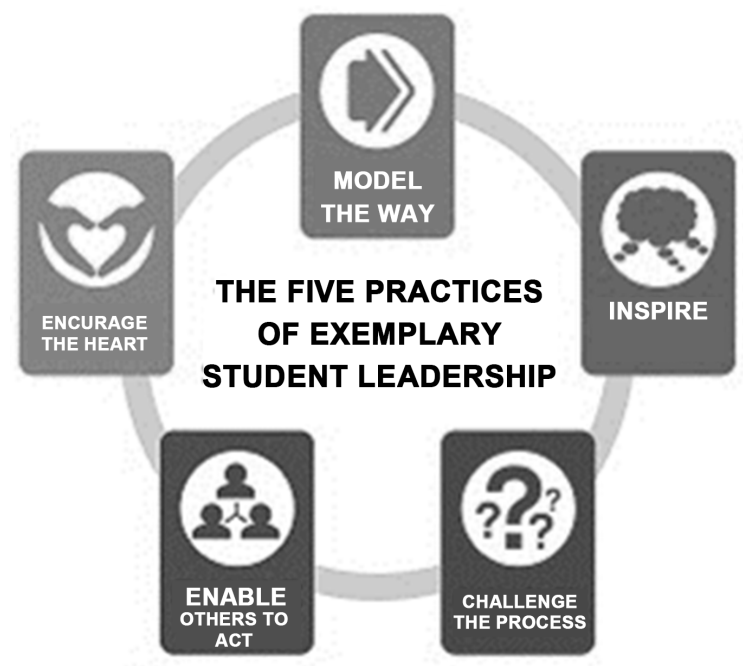

Figure 1. The Five Practices of Exemplary Student Leadership (Kouzes \& Posner, 2014). 
60 private schools, including 60 principals and 300 teachers was administered and analyzed for perceptions bear by the two groups on the effectiveness of the educational system supported in their schools in developing and nurturing student leadership skills. Results indicate that both groups of respondents displayed weak evaluation of the education systems offered by their own schools in terms of promoting student leadership. Thus, leading to the conclusion that the provision of student leadership is weak (Ghamrawi \& Al-Jammal, 2013).

Student leadership development within the Lebanese secondary schools is a critical issue worth investigating, due to its dynamic nature, implications for the future and the considerable gap of literature associated within the Lebanese context.

\section{Methodology}

This study investigated the perceptions of students regarding the concept of student leadership within the Lebanese school context. The study employed mixed methods where it used quantitative surveying alongside qualitative interviewing.

\subsection{The Sample}

The study involved 410 students from grades 10, 11 and 12, of 4 public schools in Beirut, Lebanon during the academic year (2016-2017). In addition, a focus group interview was conducted with 8 students, two from each surveyed school.

The invitation to participate in this study was administered to all 9 Lebanese public schools, located in Beirut, who were involved in a leadership development program administered by the British Council serving the Lebanese Ministry of Education and Higher Education. 4 public schools showed interest and hence participated in the study. The total number of surveys sent to students in these schools was 472. Along with a copy of the survey instrument, students received a cover letter specifying the purpose of the study, assuring anonymity and explaining how data was going to be analyzed. Out of the 472 surveys sent, only 410 were useful. Thus the sample was comprised of $\mathrm{N}=410$ public school students.

\subsection{The Research Instrument}

Participants completed a survey entitled "Student Leadership Survey (SLS)" which is an adapted form of "Leadership Practices Inventory (LPI)" survey, version (2014), constructed by Kouzes \& Posner. This survey displays the perspective of experienced adult leaders used as the trigger for responses from younger people about leadership Posner's (2004). The survey instrument uses content analysis of sentences and phrases about leadership categorized into five themes: 1) modeling the way, 2) inspiring a shared vision, 3) challenging the process, 4) enabling others to act, and 5) encouraging the heart.

The instrument consisted of 4 point Likert scale statements corresponding to 
four performance areas which are: "Rarely", "Sometimes", "Often" and "Frequently". A score of 1 indicated the public student is rarely trained on that element; a score of 2 indicated that the public student is sometimes trained on that element; a score of 3 entailed that the public student is often trained; and a score of 4 indicated that the public student is frequently trained on that element.

Additionally, public school students also completed a section on demographic information within the survey requesting them to specify their gender, age, and grade level. The researcher customized the tool and piloted it with a sample of 10 students who were attending a workshop organized by one of the researchers. Many words were amended after the conduction of the pilot study and hence the instrument was ready for administration with the actual research sample.

In addition, a 45 minutes focus group interview was conducted with 8 high school students, two from each surveyed school. The interview focused on collecting deep empathetic qualitative data about how the realization of student leadership in their schools would impact on them. For this purpose, students were presented with the five exemplary practices of student leaders as per Kouzes \& Posner (2014) and were asked to comment according to the following question: Imagine all of this was part of your school life; how do you think would this impact on you at school?

\subsection{Methods of Data Analysis}

Data was analyzed using SPSS 18.0 for windows. Descriptive statistics were used to describe and summarize the properties of the mass of data collected from the respondents. Mean scores, standard deviations and percentages were calculated per each item of the survey instrument. On the other hand, qualitative data derived from the focus group interview was analyzed using thematic-based analysis. Steps included recording the interview after permission of the school and students, transcribing data word by word and then looking up for themes by open coding, axial coding, and finally selective coding (Miles, Huberman, \& Saldana, 2014).

\section{Results}

\subsection{Demographic Data}

The student sample consisted of (42\%) males, (58\%) females, and (50.1\%) were of the age range of [15] [16] years. The majority of the public school students (53.2\%) belonged to grade 10 level. The demographic characteristics of participants are presented in Table 1.

\subsection{Research Question 1}

What are the student leadership skills that mostly prevail within Lebanese schools?

Data derived from the "Student Leadership Survey (SLS)" was used to respond to the first research question. The obtained scores which verify the first research 
Table 1. Demographic characteristics of participants.

\begin{tabular}{cc}
\hline Gender & Percentage \% \\
\hline Female & 58 \\
Male & 42 \\
\hline Age & 27.1 \\
\hline 15 yrs & 38 \\
16 yrs & 27.8 \\
17 yrs & 7.1 \\
18 yrs & \\
\hline Grade Level & 53.2 \\
10 & 32.4 \\
11 & 14.4 \\
\hline
\end{tabular}

question belong to the fourth leadership practice of the survey which consists of four skills and are presented in Table 2. In fact, the highest percentages that are recorded by the public school students reported that only the leadership competency "Enabling Others to Act" is practiced too often at their school (66.2\%). In this practice, the student leader is enabled to commit to collaborative teams and building support for those teams (Kouzes \& Posner, 1995: p. 318). In this commitment, "leaders use inclusive language in communication, use collective processes for planning and problem solving, and focus on the positive contributions of members" (Kousez \& Posner, 1995: p. 151). Kouzes and Posner make it clear that the commitment of strengthening others involves all these concepts. Remarkably, students reported the highest leadership scores in practicing the skills of treating others with dignity and respect (75.5\%) then listening actively to diverse points of views (71.2\%).

\subsection{Research Question 2}

What are students' perceptions as to how student leadership may be enhanced in their schools?

Data derived from the "Student Leadership Survey (SLS)" was used to respond to the second research question. The obtained scores which verify the second research question belong to the first, second, third, and fifth leadership practices of the survey, each practice consists of four skills that are presented in Table 3.

According to the results, the leadership practices "Model the Way" (66.6\%) and "Inspire a Shared Vision" (65.7\%) were reported to be rarely practiced at the Lebanese public schools. The practice of "Modeling the Way" recognizes the student leader as a role model. Kouzes \& Posner (1995: p. 241) claim in this practice that leaders "set the example by behaving in ways that are consistent with shared values". Leaders must themselves "know their organizations, know why they are doing what they are doing and, most importantly, make their actions mirror these beliefs" (Kouzes \& Posner, 1995: p. 232). 
Table 2. Data related to research question (1).

\begin{tabular}{|c|c|c|c|c|c|c|c|c|}
\hline Item & Enable Others to Act & $\begin{array}{l}\text { Percentage } \\
\quad(\%)\end{array}$ & $\begin{array}{l}\text { Rarely } \\
\text { (1) }\end{array}$ & $\begin{array}{l}\text { Sometimes } \\
\text { (2) }\end{array}$ & $\begin{array}{l}\text { Often } \\
(3)\end{array}$ & $\begin{array}{l}\text { Always } \\
(4)\end{array}$ & $\mathbf{M}$ & std \\
\hline 13 & $\begin{array}{l}\text { Foster cooperative rather than competitive } \\
\text { relationships among those who I work with. }\end{array}$ & & 18.5 & 30.2 & 45.4 & 5.9 & $\begin{array}{l}2.39 \\
59.7\end{array}$ & 0.85 \\
\hline 14 & Listen actively to diverse points of view. & & 3.4 & 28 & 49 & 19.5 & $\begin{array}{l}2.85 \\
71.2\end{array}$ & 0.76 \\
\hline 15 & Treat others with dignity and respect. & & 0 & 3.7 & 90.2 & 6.1 & $\begin{array}{l}3.02 \\
75.5\end{array}$ & 0.31 \\
\hline \multirow[t]{2}{*}{16} & $\begin{array}{l}\text { Support the decisions that others make on } \\
\text { their own. }\end{array}$ & & 15.9 & 42.2 & 32.4 & 9.5 & $\begin{array}{c}2.36 \\
59\end{array}$ & 0.85 \\
\hline & Total Averages & & 9.4 & 26 & 54.2 & 10.2 & $\begin{array}{l}2.65 \\
66.2\end{array}$ & 0.69 \\
\hline
\end{tabular}

As to the leadership practice "Inspire a Shared Vision", student leaders "passionately believe they can make a difference" (Kouzes \& Posner, 1995: p. 318). According to Kouzes and Posner, leaders dream of the future and find others to help them get there.

Alternatively students responded by rarely to sometimes enhanced for both leadership practices "Challenging the Process" (79.1\%) and "Encouraging the Heart" (56\%). The practice of "Challenging the Process" contributes to train students on searching out opportunities to change, grow, innovate, improve, and experimenting by taking risks and learning from mistakes. As to the leadership practice "Encouraging the Heart", students are supposed to prepare students to recognize their contributions to success and celebrate team accomplishments.

Remarkably, four practices of leadership out of five were rated the lowest by the public school students.

\subsection{Research Question 3}

How would the realization of student leadership impact on students in their schools?

Data analyzed for the purpose of responding to this research question was obtained through the focus group interview with 8 high school students: 2 from each of the researched schools. Students were presented with the five exemplary practices of student leaders as per Kouzes \& Posner (2014) and were asked to comment according to the following question: Imagine all of this was part of your school life; how do you think would this impact on you at school?

The thematic analysis of the transcribed data arrived at the following themes presented in Figure 2.

Themes emerging from the focus group interview as presented in Figure 2 indicate that students viewed student leadership very positively. In fact, students thought that when student leadership was nourished in their schools, they would tend to work harder towards achieving their goals. 
Table 3. Data related to research question (2).

\begin{tabular}{|c|c|c|c|c|c|c|c|c|}
\hline Item & Model the Way & $\begin{array}{l}\text { Percentage } \\
(\%)\end{array}$ & $\begin{array}{c}\text { Rarely } \\
(1)\end{array}$ & $\begin{array}{l}\text { Sometimes } \\
(2)\end{array}$ & $\begin{array}{l}\text { Often } \\
(3)\end{array}$ & $\begin{array}{l}\text { Always } \\
(4)\end{array}$ & $\mathbf{M}$ & std \\
\hline 1 & $\begin{array}{l}\text { Set a personal example of what I expect of } \\
\text { others. }\end{array}$ & & 17.1 & 80 & 2.9 & 0 & $\begin{array}{l}1.86 \\
46.5\end{array}$ & 0.42 \\
\hline 2 & $\begin{array}{l}\text { Follow through on promises and commitments } \\
\text { I make. }\end{array}$ & & 76.1 & 16.6 & 5.1 & 2.2 & $\begin{array}{l}1.33 \\
33.2\end{array}$ & 0.67 \\
\hline 3 & $\begin{array}{l}\text { Seek to understand how my actions affect other } \\
\text { people's performance. }\end{array}$ & & 81.7 & 10.7 & 4.4 & 3.2 & $\begin{array}{l}1.29 \\
32.2\end{array}$ & 0.69 \\
\hline 4 & $\begin{array}{l}\text { Talk about my values and the principles that } \\
\text { guide my actions. }\end{array}$ & & 91.7 & 5.1 & 1.5 & 1.7 & $\begin{array}{l}1.13 \\
28.2\end{array}$ & 0.49 \\
\hline & Total Averages & & 66.6 & 28.1 & 3.4 & 1.7 & $\begin{array}{l}1.4 \\
35\end{array}$ & 0.56 \\
\hline Item & Inspire a Shared Vision & $\begin{array}{l}\text { Percentage } \\
(\%)\end{array}$ & $\begin{array}{l}\text { Rarely } \\
(1)\end{array}$ & $\begin{array}{l}\text { Sometimes } \\
(2)\end{array}$ & $\begin{array}{l}\text { Often } \\
(3)\end{array}$ & $\begin{array}{l}\text { Always } \\
(4)\end{array}$ & $\mathbf{M}$ & std \\
\hline 5 & $\begin{array}{l}\text { Look ahead and communicate about what I } \\
\text { believe will affect us in the future. }\end{array}$ & & 89 & 6.6 & 3.4 & 1 & $\begin{array}{c}1.16 \\
29\end{array}$ & .51 \\
\hline 6 & $\begin{array}{l}\text { Talk with others about a vision of how we } \\
\text { could be even better in the future. }\end{array}$ & & 6.3 & 82.7 & 3.7 & 7.3 & $\begin{array}{c}2.12 \\
53\end{array}$ & .61 \\
\hline 7 & $\begin{array}{l}\text { Talk with others about how their own interests } \\
\text { can be met by working toward a common goal. }\end{array}$ & & 76.1 & 16.6 & 5.1 & 2.2 & $\begin{array}{l}1.33 \\
33.2\end{array}$ & 0.67 \\
\hline 8 & $\begin{array}{l}\text { Speak with passion about the higher purpose } \\
\text { and meaning of what we are doing. }\end{array}$ & & 91.7 & 5.1 & 1.5 & 1.7 & $\begin{array}{l}1.13 \\
28.2\end{array}$ & 0.49 \\
\hline & Total Averages & & 65.7 & 27.7 & 3.4 & 3 & $\begin{array}{l}1.43 \\
35.7\end{array}$ & 0.57 \\
\hline Item & Challenge the Process & $\begin{array}{c}\text { Percentage } \\
(\%)\end{array}$ & $\begin{array}{l}\text { Rarely } \\
\text { (1) }\end{array}$ & $\begin{array}{c}\text { Sometimes } \\
\text { (2) }\end{array}$ & $\begin{array}{l}\text { Often } \\
(3)\end{array}$ & $\begin{array}{l}\text { Always } \\
(4)\end{array}$ & $\mathbf{M}$ & std \\
\hline 9 & $\begin{array}{l}\text { Look for ways to develop and challenge my } \\
\text { skills and abilities. }\end{array}$ & & 65.9 & 29.5 & 4.6 & 0 & $\begin{array}{l}1.39 \\
34.7\end{array}$ & 0.57 \\
\hline 10 & $\begin{array}{l}\text { Look for ways that others can try out new ideas } \\
\text { and methods. }\end{array}$ & & 88.8 & 7.6 & 3.7 & 0 & $\begin{array}{l}1.15 \\
28.7\end{array}$ & 0.44 \\
\hline 11 & $\begin{array}{l}\text { Learn experiences from the things that do not } \\
\text { go as expected. }\end{array}$ & & 15.9 & 42.2 & 32.4 & 9.5 & $\begin{array}{c}2.36 \\
59\end{array}$ & 0.85 \\
\hline 12 & $\begin{array}{l}\text { Make sure that big projects we undertake are } \\
\text { broken down into smaller and do-able parts. }\end{array}$ & & 24.4 & 42.4 & 32 & 1.2 & $\begin{array}{l}2.10 \\
52.5\end{array}$ & 0.77 \\
\hline & Total Averages & & 48.7 & 30.4 & 18.1 & 2.6 & $\begin{array}{l}1.75 \\
43.7\end{array}$ & 0.65 \\
\hline Item & Encourage the Heart & $\begin{array}{c}\text { Percentage } \\
(\%)\end{array}$ & $\begin{array}{l}\text { Rarely } \\
\text { (1) }\end{array}$ & $\begin{array}{c}\text { Sometimes } \\
\text { (2) }\end{array}$ & $\begin{array}{l}\text { Often } \\
\text { (3) }\end{array}$ & $\begin{array}{l}\text { Always } \\
\text { (4) }\end{array}$ & $\mathbf{M}$ & std \\
\hline 17 & Praise others for a job well done. & & 24.4 & 42.4 & 32 & 1.2 & $\begin{array}{l}2.10 \\
52.5\end{array}$ & 0.77 \\
\hline 18 & $\begin{array}{l}\text { Encourage others as they work on activities } \\
\text { and tasks. }\end{array}$ & & 89 & 6.6 & 3.4 & 1 & $\begin{array}{c}1.16 \\
29\end{array}$ & 0.51 \\
\hline 19 & $\begin{array}{l}\text { Express appreciation for the contributions that } \\
\text { others make. }\end{array}$ & & 15.9 & 42.2 & 32.4 & 9.5 & $\begin{array}{c}2.36 \\
59\end{array}$ & 0.85 \\
\hline 20 & Find ways to celebrate accomplishments. & & 0 & 3.7 & 90.2 & 6.1 & $\begin{array}{l}3.02 \\
75.5\end{array}$ & 0.31 \\
\hline & Total Averages & & 32.3 & 23.7 & 39.5 & 4.4 & $\begin{array}{c}2.16 \\
54\end{array}$ & 0.61 \\
\hline
\end{tabular}




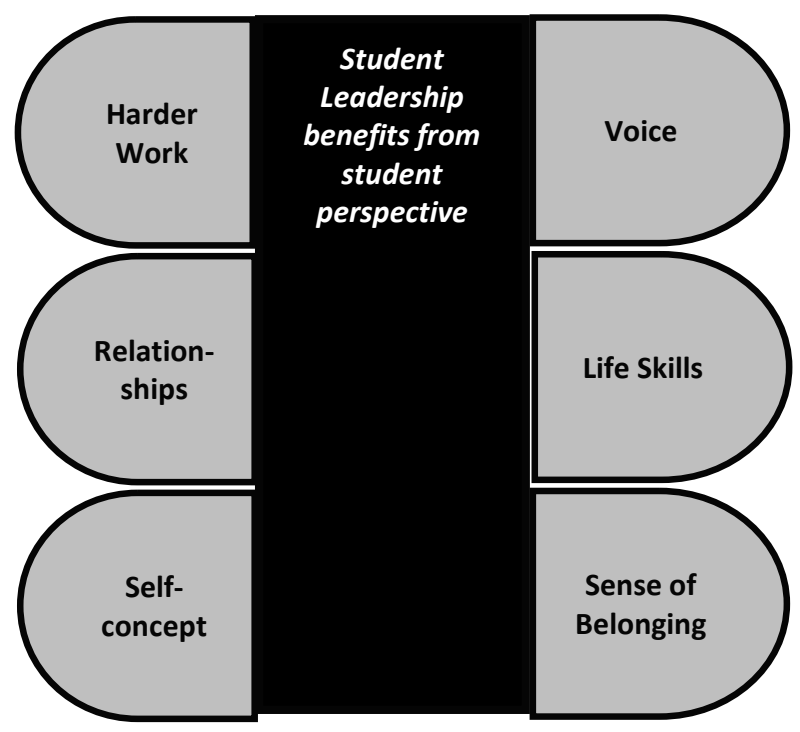

Figure 2. Themes emerging from the focus group interview about student leadership.

"I think I will be very much to study harder and achieve more" ( $\left.S B 2^{1}\right)$

"That would be a great incentive for me to study more, and do all my best" $(S D 1)$

This was attributed to another factor which is relationships, where students thought that one of the reasons that would push them to work harder would be the fact that they would enjoy better relationships with their teachers and school administration.

“... so by this, the school would turn a nice place for us to be in and we would have good relations with our teachers and school principap' (SA1)

"I think we would be able to achieve goals through the strong relationships that such a school would allow to" ( $S B 1)$

Students also believed that when student leadership is established and nourished in school, their sense of belonging to school increases.

"I would definitely feel better about my school and about being in it" (SA2)

"I think I would prefer to live in the school rather than at house if this is how school would look like" (SD2)

One of the most important reasons they attributed to why they would enjoy a stronger sense of belonging was that their voice would be heard.

".... because at least I would be sure that all the problems we face at school will be channeled to the principal and we can discuss it without fear with her" (SC2)

"Schools that allow this [student leadership] helps students voice to get heard and respected" (SC1)

Moreover, students thought that with student leadership they would better acquire skills they needed to survive not only at school but later on in life.

${ }^{1}$ This is the way every interviewee was represented in the transcription where S: school - B: representation of schools (A, B, C, D) - 2: the number given to the student within the same school (1 or 2). 
"I believe I will learn how to talk, how to solve problems both in and out of schools" (SD1)

"I think I would learn how to deal with bullies as I will be a stronger person" $(S B 2)$

Finally, students thought that student leadership would improve their self-images as it would make them more confident about their skills and capabilities.

"This environment would allow me to get all the skills I need to be confident in myself I would feel better about myself" (SBI)

"I think it [Student leadership] would make me love life and myself more"

\section{Summary}

A growing body of research suggests that school leadership must be transformed before education can be reformed (Bush \& Glover, 2012). The developmental forms of school leadership, high student achievement and positive school cultures are interrelated (Ghamrawi, 2016). In Lebanon, there is a growing awareness within the Ministry of Education \& Higher Education (MEHE) of the importance of school leadership, and is translated through the training of public school principles on leadership matters (Ghamrawi, 2016).

This study investigated the perceptions of students regarding the concept of student leadership within the Lebanese school context; an area of research that, to the knowledge of the researcher, has been little addressed in Lebanon. Findings indicate that students viewed areas of strengths and weaknesses for student leadership within the Lebanese public schools. The student leadership practice of "Enabling Others to Act" was reported by the students to be strengthened through fostering cooperative rather than competitive relationships, listening actively to diverse points of view, respecting others, and supporting others.

On the contrary, students reported a set of leadership practices that were weakly enhanced through the learning opportunities that were granted to them within the researched Lebanese public schools. These practices included "Modeling the way", "Inspiring a shared vision", "Challenging the process", and "Encouraging the heart". Student leaders are supposed to model leadership through setting a personal example of what to expect from others, following commitments, seeking the consequences of their actions, and taking about values that guide their actions. Additionally, they are expected to inspire a shared vision through communicating beliefs, talking about future visions and their interests influencing their future goals, and describing higher ordered purposes. Also, students learn to challenge the processes when looking for ways to develop their skills, trying new ideas, and experiences. In addition, they need to encourage the heart through learning to encourage other achievements, contributions and accomplishments.

Students highly valued student leadership and considered its establishment a mean for them to having increased self-belonging to their school, getting com- 
mitted to harder work towards achieving goals, having their voice better heard at school, acquiring lifelong skills, enjoying better relationships at school, and relishing improved self-concepts.

\section{Conclusion}

This study provides empirical data for an under researched topic and sample within the Lebanese context: student leadership within the public school sector. It shows that student leadership still has large milestones to be realized and nourished within the Lebanese public school system. Yet, it has shown through the lens of a tiny sample of students that it can do a lot to them should they get granted the opportunity to practice leadership. Interestingly, students did not view student leadership as means for getting "more powerful" but rather to better belong to the school community and feel better about themselves.

\section{Limitations of the Research}

Two factors limited the scope of the study. First, the study was confined deliberately to limited number of Lebanese public schools due to problems accessing other schools due to MEHE bureaucracy. The second limiting factor was that only one focus group was allowed to happen due to constraints from the researched schools. With more focus group interviews more in-depth information would have enriched findings.

\section{Recommendations}

This study suggests that student leadership is of considerable value to students' personal growth, and to the positive cultivation of school culture. This study was limited to public schools throughout Lebanon. It would be informative if future research employs a more representative sample of schools. The involvement of private schools would give a more comprehensive picture of the reality of student leadership in schools.

\section{References}

Adams, T. C., \& Keim, M. C. (2000). Leadership Practices and Effectiveness among Greek Student Leaders. College Student Journal, 34, 259-261.

Black, R., \& Walsh, L. (2009). Corporate Australia and Schools: Forming Business Class Alliances and Networks. Seminar Series Paper 182. Melbourne: Centre for Strategic Education.

Bowman, R. F. (2014). Learning Leadership Skills in High School. The Clearing House: A Journal of Educational Strategies, Issues and Ideas, 87, 59-63. https://doi.org/10.1080/00098655.2013.842533

Bush, T., \& Glover, D. (2012). Distributed Leadership in Action: Leading High-Performing Leadership Teams in English Schools. School Leadership and Management, 32, 21-36. https://doi.org/10.1080/13632434.2011.642354

Chapman, J., \& Aspin, D. (2001). Schools and the Learning Community: Laying the Basis for Learning across the Lifespan. In D. S. Aspin, J. D. Chapman, M. Hatton, \& Y. Sa- 
wano (Eds.), International Handbook on Lifelong Learning Part 2 (pp. 405-446). Dordrecht: Kluwer Academic Publishers. https://doi.org/10.1007/978-94-010-0916-4_22

Cress, C. M., Astin, H. S., Zimmerman-Oster, K., \& Burkhardt, J. C. (2001). Developmental Outcomes of College Students' Involvement in Leadership Activities. Journal of College Student Development, 42, 15-27.

Day, K. (2013). Leadership Theory. http://prezi.com/tm8vsu8oujur/leadership-theory/

Dempster, N. (2006). Leadership for Learning: Possible Links at the Gap State High School. Leading and Managing, 12, 54-63.

Department of Education and Early Childhood Development (DEECD) (2009). Effective Schools Are Engaging Schools: Student Engagement Policy Guidelines. Promoting Student Engagement, Attendance and Positive Behaviors in Victorian Government Schools. Melbourne: Department of Education and Early Childhood Development.

Dewey, J. (1916/2012). Democracy and Education. New York, NY: Courier Dover Publications.

Dial, D. (2006). Students' Perceptions of Leadership and the Ways in Which Leader Shape Influences the Development of Student Leaders. Master Thesis, Liberal: Graduate Faculty of the Louisiana State University and Agricultural and Mechanical College.

EFA (2012). Education for All: Global Monitoring Report. Paris: UNESCO. http://en.unesco.org/gem-report/

Eich, D. (2008). A Grounded Theory of High-Quality Leadership Program: Perspectives from Student Leadership Development Programs in Higher Education. Journal of Leadership \& Organizational Studies, 15, 176-187. https://doi.org/10.1177/1548051808324099

Friedman, A. A. (2004). Beyond Mediocrity: Transformational Leadership within a Transactional Framework. International Journal of Leadership in Education, 7, 203-224. https://doi.org/10.1080/1360312042000213877

Gannon, M. (2001). Cultural metaphors. London: Sage.

Ghamrawi, N. (2011). Trust Me: Your School Can Be Better-A Message from Teachers to Principals. Educational Management Administration \& Leadership, 39, 333-348. https://doi.org/10.1177/1741143210393997

Ghamrawi, N. (2016). Policy Review of School Leadership in the Arab States. Leading Better Learning: School Leadership and Quality in the Education 2030 Agenda: Regional Reviews of Policies and Practices. UNESCO Education Sector Division for Policies and Lifelong Learning Systems (ED/PLS) Section of Education Policy (ED/PLS/EDP), January 2016.

Ghamrawi, N., \& Al-Jammal, K. (2013). Leadership versus Management: Between Self-Concept and Actual Practice of Lebanese School Principals. International Journal of Educational Research and Technology, 4, 56-72.

Ghamrawi, N., Ghamrawi, N. A. R., \& Shal, T. (2017). Lebanese Public Schools: $20^{\text {th }}$ or $21^{\text {st }}$ Century Schools? An Investigation into Teachers' Instructional Practices. Leadership, 6, 1-20. https://doi.org/10.4236/ojl.2017.61001

Grogan, M., \& Shakeshaft, C. (2010). Women and Educational Leadership (Vol. 10). New York: John Wiley \& Sons.

Hirsch Jr., E. D. (2010). The Schools We Need: And Why We Don't Have Them. New York: Anchor.

Komives, S. R. (2011). The Social Change Model of Leadership Development. http://www.youtube.com/watch?v=PpjGCP5eek\&list=WLB3ABF24B77D94AC4

Komives, S. R., Dugan, J. P., \& Owen, J. E. (2011). The Handbook for Student Leadership 
Development. New York: John Wiley \& Sons.

Kouzes, J. M., \& Posner, B. Z. (1995). The Leadership Challenge (2nd ed.) San Francisco, CA: Jossey-Bass.

Kouzes, J. M., \& Posner, B. Z. (2014). The Student Leadership Challenge: Five Practices for Becoming an Exemplary Leader. New York: John Wiley \& Sons.

Lavery, S. (2006). Student Leaders: So Many Reasons to Bother. Principal Matters, 69, 27-28.

Leithwood, K., Seashore, K., Anderson, S., \&Wahlstrom, K. (2004). Executive Summary: Review of Research: How Leadership Influences Student Learning.

Locke, E. A. (1999). The Essence of Leadership: The Four Keys to Leading Successfully. New York: Lexington Books.

McInerney, P. (2009). Toward a Critical Pedagogy of Engagement for Alienated Youth: Insights from Freire and School-Based Research. Critical Studies in Education, 50, 23-35. https://doi.org/10.1080/17508480802526637

Miles, M. B., Huberman A. M., \& Saldana J. (2014). Qualitative Data Analysis (3rd ed.). A Methods Sourcebook. New York: Sage Publications.

Partnership for 21st Century Skills (2011). Taking Differentiation Further to Provide Individualized Learning Experiences. http://www.p21.org

Pedersen, J., Yager, S., \& Yager, R. (2012). Student Leadership Distribution: Effects of a Student-Led Leadership Program on School Climate and Community. NCPEA Publication.

Posner, B. Z. (2004). A Leadership Development Instrument for Students: Updated. Journal of College Student Development, 45, 443-456. https://doi.org/10.1353/csd.2004.0051

Rost, J. C. (1993). Leadership for the Twenty-First Century. Santa Barbara, CA: Greenwood Publishing Group.

Ruderman, M. N. (2004). Leader Development across Gender. In C. D. McCauley, \& E. Van (Eds.), Center for Creative Leadership Handbook of Leadership Development (p. 274), New York: John Wiley \& Sons.

Spillane, J. P. (2005). Distributed Leadership. The Educational Forum, 69, 143-150. https://doi.org/10.1080/00131720508984678

Steinberg, S., \& Li, X. (2014). White Paper: Empowering Students as Leaders in Alberta. $A$ Literature Review, 31, 2014.

Tuohy, D. (1999). The Inner World of Teaching: Exploring Assumptions Which Promote Change and Development. London: Falmer Press.

UNDP (United Nations Development Programme) (2013). The Rise of the South: Human Progress in a Diverse World. New York: UNDP.

Van Velsor, E., \& Wright, J. (2012). Expanding the Leadership Equation: Developing Next-Generation Leaders. ERIC: Center for Creative Leadership White Paper. http://files.eric.ed.gov/fulltext/ED543117.pdf

Walsh, L., \& Black, R. (2011). Students in the Lead: Increasing Participation by Young People. In V. Zbar, \& T. Mackay (Eds.), Leading the Educational Debate (Vol. 3). East Melbourne: Centre for Strategic Education. 